\title{
Abstracts from the 39th Annual National Student Research Forum
}

\author{
Galvaston, Texas, USA*
}

\section{CHARACTERIZATION, CHOLINERGIC REGULATION, AND FUNCTIONAL SIGNIFICANCE OF LARGE CONDUCTANCE $\mathrm{CA}^{2+}$-DEPENDENT $\mathrm{K}^{+}$CHANNELS IN HUMAN ESOPHAGEAL SMOOTH MUSCLE CELLS}

\author{
B. Hurley, H.G. Preiksaitis, S.M. Sims
}

Department of Physiology, University of Western Ontario, London, Ontario, Canada

Investigations were undertaken to examine cholinergic regulation of ion channels in human esophageal smooth muscle cells. Measurements of channel activity were made in the cell-attached patch configuration. Acetylcholine (ACh) was shown to cause contraction and a transient increase in activity of a channel whose properties were consistent with the large conductance calcium activated potassium channel (KCa). Addition of caffeine also led to activation of this $\mathrm{K}^{+}$channel, and effects of both $\mathrm{ACh}$ and caffeine persisted in $\mathrm{Ca}^{2+}$ free solution. It is concluded that effects of ACh were mediated by the release of $\mathrm{Ca}^{2+}$ from intracellular stores and that entry of extracellular calcium is not required to activate $\mathrm{KCa}$ channels. Simultaneous patch-clamp and calcium fluorescence recording allowed quantification of the calcium sensitivity of this $\mathrm{KCa}$ channel. Studies using tetra-ethyl ammonium (TEA), a blocker of the KCa channel, demonstrated that inhibition of this channel increased the magnitude and duration of muscle contraction in response to ACh. These studies are the first to characterize $\mathrm{KCa}$ channels in human esophageal muscle

\footnotetext{
* Held by the University of Texas Medical Branch at Galvaston on April 16-18, 1998.
}

and to demonstrate the role of $\mathrm{KCa}$ channels in limiting depolarization of smooth muscle.

Bernard Hurley was awarded the Sigma Xi Award for Overall Excellence of Research and the Mason Guest Memorial Award.

\section{INCREASED VASCULAR ALPHA2-RECEPTOR RESPONSIVENESS WITH INDOMETHACIN: IN VIVO EVIDENCE FOR DECREASED VASODILATOR PROSTAGLANDIN RELEASE IN PATIENTS WITH MILD TO MODERATE CONGESTIVE HEART FAILURE}

\author{
I.D. Callow, N. Dzeka, J. Malcolm, O. Arnold
}

Departments of Medicine and Dentistry and of Pharmacology and Toxicology, University of Western Ontario, London, Ontario, Canada

In patients with mild to moderate congestive heart failure (CHF), the current authors have previously demonstrated that venous $\alpha$-receptor responsiveness is increased compared with normal controls. This finding was unexpected. It was subsequently demonstrated in young normal subjects that endothelial vasodilator prostaglandins (PG's) are released secondary to venous $\alpha 2$-receptor activation and decrease the net venoconstriction. Since endothelial function is impaired in $\mathrm{CHF}$, it was hypothesized that the prostaglandin synthesis inhibitor, indomethacin, would increase venoconstriction to clonidine in age-similar normals but would have no effect on venoconstriction to clonidine in patients with CHF. Patients $(64.0 \pm 3.7 \mathrm{yrs}$, 
mean \pm sem) with mild to moderate CHF (left ventricular ejection fraction: $23.8 \pm 3.5 \%$ ) and 7 agesimilar $(65.3 \pm 2.6$ yrs $)$ normal subjects were each studied on two separate days. Graded local infusions of the $\alpha 2$-noradrenergic receptor agonist clonidine (3 to $7000 \mathrm{ng} / \mathrm{min}$ ) were administered into a dorsal hand vein in conjunction with either indomethacin ( $3 \mathrm{mg} / \mathrm{min})$ or saline placebo. Venous distention at $45 \mathrm{mmHg}$ was measured using a hand vein tonometry technique. Dose-response curves to clonidine were constructed and the maximum hand vein constriction calculated. No systemic effects of clonidine or indomethacin were observed. The dose-response curve to clonidine was shifted to the left in CHF patients compared to normals ( $p=0.05$ ) consistent with our previous findings. However, with indomethacin co-infusion, the clonidine curve in normals was displaced up and to the left $(p<0.01)$ (to the level seen in CHF patients during saline co-infusion) but remained unchanged in $\mathrm{CHF}$ patients. Maximum venoconstriction to clonidine was increased with indomethacin compared to saline $(44.1 \pm 5.8 \%$ vs. $17.8 \pm 3.7 \%, p<0.01)$ in normal controls but remained unaltered in patients with $\mathrm{CHF}$ $(40.5 \pm 7.6 \%$ vs. $39.0 \pm 6.0 \%)$. These results are consistent with our hypothesis that $\alpha 2$-receptor stimulation normally releases endothelial vasodilatory PG's which antagonize the venoconstrictor response to clonidine and modulate the sympathetic vascular response. Increased alpha receptor mediated constriction may contribute to progression of $\mathrm{CHF}$ and may also be relevant in other diseases with endothelial dysfunction.

Ian D. Callow was awarded the George I. Ellis Memorial Award.

\section{PERSISTENCE OF INFECTIOUS HEPADNAVIRUS IN OFFSPRING BORN TO MOTHERS CONVALESCENT FROM HEPATITIS IN THE WOODCHUCK MODEL OF HEPATITIS B}

\author{
C.S. Coffin, T.I. Michalak
}

Faculty of Medicine, Memorial University of Newfoundland, St. John's, Newfoundland, Canada

Hepatitis B virus (HBV) is a hepatotropic virus, but it can also replicate in lymphoid cells. The virus induces life-threatening liver diseases, such as cirrhosis and hepatocellular carcinoma, and there are more than
300 million chronic HBV carriers worldwide. Transmission of HBV from mothers to babies is the most important route for virus spread within the population. Recent findings have established the existence of a serologically silent $\mathrm{HBV}$ persistence in healthy individuals convalescent from acute hepatitis B. In these patients, traces of $\mathrm{HBV}$ genomes were documented years after recovery. Similar data has been obtained in a woodchuck model of hepatitis B in this laboratory. Woodchuck hepatitis virus (WHV) is closely related to HBV and provides an excellent model for the study of HBV pathogenicity. This study was undertaken: (i) to determine whether hepadnaviral genomes can be transmitted from maternal woodchucks with a past episode of acute WHV hepatitis to their offspring; (ii) if so, to identify reservoirs of hepadnavirus replication during long-term follow-up of these newborn animals; (iii) to characterize physicochemical properties of molecules carrying WHV DNA in sera of these offspring; (iv) to test whether silent carriage of WHV genomes acquired after vertical transmission reflects the existence of biologically competent virus infectious to WHV-naive woodchucks. In this work, 11 offspring born to four woodchuck mothers were investigated. The results have shown that serologically silent WHV carriage acquired after recovery from an episode of viral hepatitis is transmittable to newborns as an asymptomatic chronic infection. Importantly, all of the offspring tested carried WHV DNA through the entire follow-up, lasting for more then three years after birth, and remained nonreactive for serological markers of WHV infection. WHV DNA and RNA specific sequences were detectable both in the liver and lymphoid cells in the majority of the animals, although in some offspring WHV persisted exclusively at a extrahepatic location in the lymphatic system. Particles carrying WHV DNA in sera of offspring with WHV genomes in both the liver and lymphoid cells or the lymphatic system alone had physicochemical properties comparable to those of complete WHV virions. In addition, virus contained in offspring sera with or without WHV DNA expression in the liver, as well as culture supernatant from mitogenstimulated peripheral blood mononuclear cells, were infectious to WHV-naive woodchucks. Since there are significant pathobiological similarities between HBV and WHV, it is possible that a comparable situation may exist in babies born from mothers with a past history of hepatitis B.

Carla S. Coffin was awarded the McLaughlin Award in Infectious Disease. 